\title{
Colour stability of the flowers in some modern rose varieties in Hungary
}

\author{
Boronkay, G. ${ }^{1}$, Jámbor-Benczúr, E. ${ }^{2}$ \& Máthé, Á. ${ }^{3}$ \\ ${ }^{\prime}$ Research Institute for Fruitgrowing and Ornamentals, H-1223 Budapest, Hungary \\ ${ }^{2}$ Corvinus University of Budapest, Faculty of Horticultural Science, Department of Floriculture and Dendrology, \\ H-1118 Budapest, Hungary \\ ${ }^{3}$ University of West Hungary, Faculty of Agriculture and Food Science, 9200 Mosonmagyaróvár, Hungary
}

Summary: A variety trial has been carried out to study the colour changing - colour stability of the flowers of some modern roses, especially of Hungarian varieties. 100 floribundas and polyanthas were observed. Colours of the petal surface were examined at three fenological stages of the flowers: at the bud, at the young open flowers and at the aged open flower stages. The colour difference was described in HLS standard. Our work shows that valuable Hungarian varieties can be found in both studied classes, but more floribundas bred in Hungary had good colour stability than polyanthas. The best Hungarian floribundas were 'Pest' and 'Reményik Sándor emléke', although 'Régen', 'Szent László emléke' and 'Szabó Dezsö emléke' were quite good. The best Western-European floribunda rose was 'Perneille Poulsen'. Their colour stability was reliable in different situations. Colour changing of the two best varieties was almost unperceivable from the bud to the young petals and from the young to the aged petals. In the polyantha class there was only one perfect variety: the Czech 'Csl Cerveny Kriz'. The 'Fairy Damsel' was almost excellent as well. The best Hungarian polyanthas were 'Domokos Pál Péter emléke' and 'Savaria'.

Key words: rose, floribunda, polyantha, climbing, blooming, flowering, variety trial, Hungarian

\section{Introduction}

In Hungary, the Research Institute for Fruitgrowing and Ornamentals has been maintaining a rose garden since the 1960 's. The rich collection of nearly 1.5 thousand varieties provides excellent opportunity for the evaluation of Hungarian and well known foreign rose varieties. Unlike the experiments by Palai et al. (2003), which concentrate on hybrid varieties and greenhouse productions, we wanted to place the floribunda and polyantha classes in focus.

The most impressive feature of the garden rose is the mass of the flowers. The good rose varieties can create solid, vivid patches of colour, white, yellow, pink, red, etc., or sometimes a multicoloured carpet. Therefore the quality of the flower colour is a very important part of the variety evaluation. There are publications, in witch the main task was to determine the exact colour(s) of the petals, for example Zhenjang et al. (2005). The main aim of their work was to specify the varieties as accurately as possible. Other works studied the environmental influences on the colour intensity, for example the effect of low light conditions and different sucrose levels (Uddin et al., 2001). In spite of the fact, that the petal colour is the most prominent feature of the rose flower, the exact colour itself does not determine the value of a variety, since it is a matter of taste. A golden yellow rose is not more valuable than a light yellow one. In the evaluation of the garden roses, colour stability seems to be even more important. Flower in any colour can be valuable, but the best roses must have good colour stability, without faded or spotted petals. It is especially true in public parks, because dead-heading cannot always be carried out in such locations. In view of these considerations, we have decided to study the colour stability of some new Hungarian varieties and foreign roses in our rose garden.

Our studies were carried out in two stages, in 2002 and 2003. In stage I, the blooming intensity and in stage II, the discolouring of the flowers was studied. In 2003, the petal colour of the varieties was studied: it was recorded how intensive the fading and the changing of petal colour was.

Beyond the examined characters of the colours there are a number of features that are under strong influence of fashion, for example scent, shape and general colour of the flowers. These subjective characters have not been studied.

\section{Materials and methods}

\section{Varieties}

This variety evaluation was carried out in Budapest, at the Budatétény Rose Garden, in 2003. The following varieties were studied: Hungarian bred roses: 35 floribundas and 18 polyanthas and as control, Western-European roses from our collection: 35 floribundas and 12 polyanthas. The names and 
classifications of rose varieties are according to the American Rose Society "ARS approved exhibition name" (Cairns et al., 2000), Hungarian lists of varieties (Rátkai, 2001), and breeders' lists of the Hungarian variety candidates (Márk, 2004). The the assessed rose varieties are the following in alphabetical order ( $\mathrm{po}$ - polyantha, $\mathrm{fl}$ - floribunda):

Ady Endre emléke (fl Márk -) - carmine red, , Apor Péter emléke (po Márk -) - red, Ȧrpảd (po Márk 2002) salmon red, Athos (fl Laperriere 1965) - orange red, Attila (fl Márk -) - dark red, Barbecue (fl Dickson 1961) - red, Báthory István emléke (fl Márk -) - bright red, Beauty of New South Wales (po Knight 1931) - bright pink - white, Bethlen Gábor emléke (fl Márk 1997) - dark pink, Bodor Péter emléke (po Márk 1998) - lighr pink, Border King (po deRuiter 1952) - light red, Borsod (fl Márk -) - bright red, Brillant Star (fl Watkins Roses 1965) - bright red - yellow, Chanalle (fl McGredy 1959) - pink shades, Chic Parisien (fl DelbardChabert 1956) - soft pink, Colisée (fl Gaujard 1965) reddish pink, Csinszka (po Márk 2002) - purple pink, Csl Cerveny Kriz (po Böhm 1937) - carmine, Déryné (fl Márk -) - soft pink, Dẻva (po Márk -) - red, Diabolo (fl Gaujard 1958) - dark salmon, Dick Koster Fulgens (po Koster 1940) - light red, Domokos János emléke (fl Márk 1997) - golden yellow, Domokos Pál Péter emléke (po Márk 1998) - salmon red, Dsida Jenö emléke (po Márk 1996) - yellow-pink-red, Elsbeth Meyer (po Vogel 1940) - dark red, Erzsébet királyné emléke (fl Mark -) - soft pink, Fairy Damsel (po Harkness 1982) - soft pink, Fresco (fl deRuiter 1968) - orange yellow, Garden Princess (fl Leenders 1961) - yellow, Gelence (fl Márk -) - carmine, Gold Badge (fl Paolino 1978) - lemon yellow, Golden Perfume (fl Leenders 1959) - orange - gold, Golden Slippers (fl Von Abrams 1961) - yellow - red, Gül Baba (fl Márk 2000) - bright red, Gustav Strobel emléke (po Márk -) - bright pink, Happy (po deRuiter 1954) carmin red, Happy Event (fl Dickson 1964) - yellow - pink, Háry Jảnos (po Márk -) - bright pink, Hollandia (po deRuiter 1958) - dark red, Hungaria (f1 Müller 1965) - light red, Ilma (fl Márk -) - dark red, Ingrid Stenzig (po Hassefras Bros. 1951) - pink, Insel Mainau (fl Kordes 1959) - carmine, János vitéz (fl Márk -) - salmon red, Jókai Mór emléke (po Márk -) - salmon - red, Kovászna (fl Márk -) - salmon red, Kund Abigél (fl Márk -) - purple red, La Sevillana (fl Meilland 1978) - bright red, La Voulzie (fl Robichon 1953) - dark red, Laborfalvi Róza emléke (fl Márk -) - dark pink, Lágymányos (fl Márk 2000) - light red, Leila (fl Márk -) - light pink, Lilli Marleen (fl Kordes 1959) - medium red, Liu (fl Márk -) - white - carmine, Max Holder ( fl Márk 2000 ) - pink, Mikszáth Kálmán emléke (po Márk -) - yellow - pink, Millecentenárium'96 (fl Márk 1996) - soft pink, Minuette (fl Lammerts 1969) - white - red, Montijo (fl Dot 1954) carmine, Mothers'day (po Grootendorst 1949) - dark red, Mrs.Joseph Hiess (po Shepherd 1943) - pink, Munkács (fl Márk -) - bright red, Nagyvárad (po Márk -) - light red, New Daily Mail (fl Tantau 1972) - dark red, Nina Weibul (fl Poulsen 1962) - dark red, Nouvelle Europe (fl Gaujard 1964) - orange red, Okályi Iván emléke (fl Márk 1997) - salmon red, Orange Triumph Improved (po Cant 1960) - orange red,
Örség (fl Márk -) - red - pink, Pernille Poulsen (fl Poulsen 1965) - light pink, Pest (fl Márk 1993) - dark red, Picasso (fl McGredy 1971) - red - white, Poppy Flash (fl Meilland 1971) - orange red, Ráskai Lea (fl Márk 2002) - light yellow, Régen (fl Márk 2000) - light pink, Rekordblüher (fl Tantau 1965) - rose pink, Reményik Sándor emléke (fl Márk -) bright pink, Rosali (fl Tantau 1983) - medium pink, Sanktflorian (fl Meilland 1971) - medium red, Savaria (po Márk -) - carmine red, Scania (fl deRuiter 1965) - dark red, Sunsprite (fl Kordes 1977) - golden yelow, Szabó Dezső emléke (fl Márk 1998) - bright red, Szárazajta (fl Márk -) bright red, Szendrey Júlia emléke (po Márk -) - light medium pink, Szent Gellért (fl Márk 1998) - soft pink, Szent László (fl Márk 2002) - carmine, Szent Margit (fl Márk 1997) - white, Táncsics Mihály emléke (po Márk -) - bright red, Tantau's Surprise (fl Tantau 1951) - bright red, Taranga (fl Tantau 1982) - medium red, Tihany (po Márk -) - orange - pink - red, Tornado (fl Kordes 1973) - orange red, Vak Bottyán emléke (fl Márk -) - dark pink, Verecke (po Márk -) - pink shades, Violet Carson (fl McGredy 1964) - pink silver, Vörössipkások emléke (fl Márk 1998) - bright red, Zảgon (fl Márk -) - salmon pink, Zirc (po Mảrk-) - pink.

\section{Site of experiments}

The experimental garden is situated in the southern part of Budapest, in Budatétény. It is located on the margin of the north-western region of the Hungarian Great Plain, the most characteristic geographical part of the country. The typical climate of the Great Plain is continental, characterised by cold winters, frosty springs, hot and dry summers. The rainiest months are May and June. The meteorological and geographical data of Budatétény are the following: 102-110 metres above sea level, the soil is rendzina; the relief type is dissected plain. The mean January temperature is $-2--1^{\circ} \mathrm{C}$, the mean July temperature is $18-20^{\circ} \mathrm{C}$. Mean annual absolute minimum temperature: $-15-16^{\circ} \mathrm{C}$, mean annual absolute maximum temperature: $33^{\circ} \mathrm{C}$. The average annual precipitation is $600 \mathrm{~mm}$. (Pécsi, 1989)

\section{Meteorological condition}

The weather in the two years of the experiment was almost "perfect" for evaluating dry-climate tolerant varieties, because the temperature and the precipitation were critical in that summer.

In 2003, the spring and the summer were extremely hot, and arid, an unusual warm wind came from Africa. In addition, due to the wind, the surface of the soil was continuously dry, and atmospheric drought could be observed: the air was very dry throughout the year. See Figure $l$ on the weather of the Rosarium in 2003.

\section{Care of plants}

The varieties were planted in rows into beds, in 19931995, with 8-10 stocks in each row. During the experiment, 


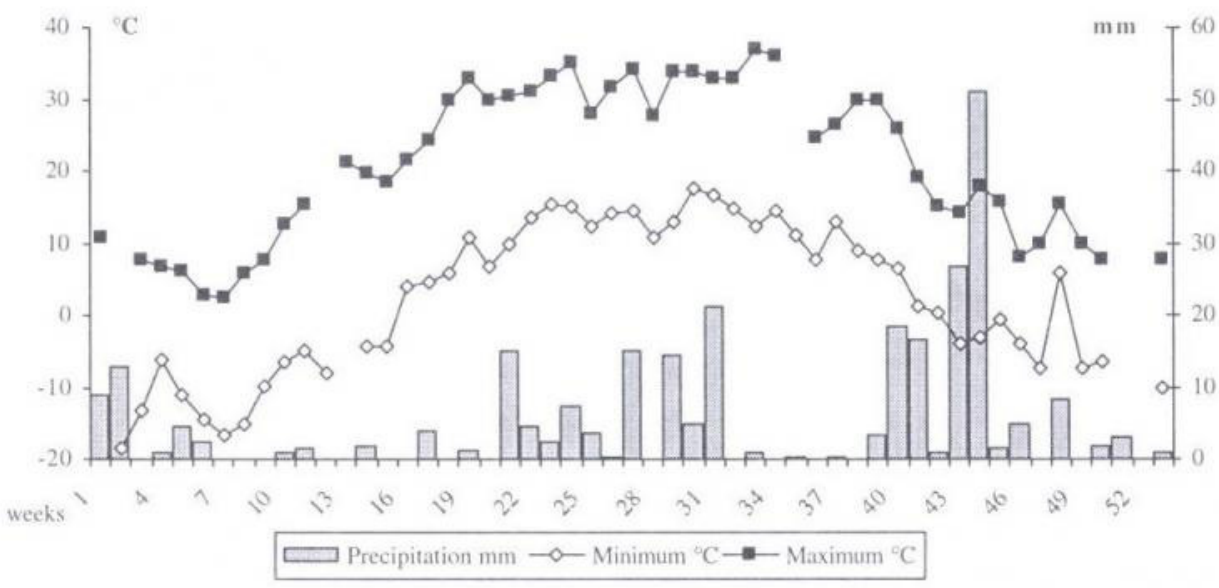

Figure $I$ Weekly maximum and minimum temperature and precipitation in the year 2003 according to the metrological station at the Rose Garden.

the rose plantation received only the essential maintenance, for example no irrigation was deployed in summer. The garden received as much pruning, weeding and plantprotection spraying as Hungarian parks usually do.

\section{Determination of the discolouring}

The question, which petal colour is the most decorative, is a matter of taste, though a fading flower is disadvantageous. Nonetheless, sometimes, a very strong shift in flower colour can be attractive. Masquerade (floribunda, Boerner, 1949) - a well-known old variety - is a good example of it.

The colours of the flowers were measured between 2 and 9 July 2003. They were specified according to "Pantone Colour Formula Guide 2002-2003 Printer Edition” colour cards. Although this colour-set is not supposed to be used in

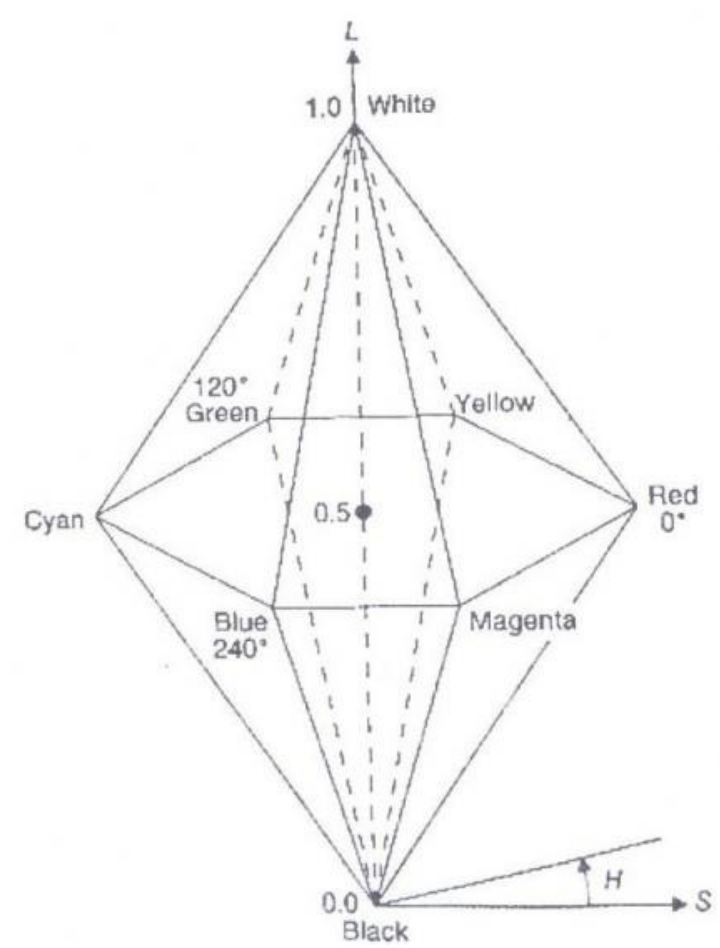

Figure 2. Section view of the HLS colour model (from J. BRADLEY online) botany, it has proved to be more useful, than the RHS Colour Chart (1986), because the physical parameters of each colour of the card are determined, and can be used. RHS Colour chart still needs identifying (H: Voss, 1992)

First, the Pantone colour codes were recorded with comparing the colour cards to the petals in a shaded but sunny place. After that, the colour data were converted to the standard HLS (hue-luminosity-saturation) system by means of Corel! Photo-Paint 9 (version number 9.397). It gives exact HLS values for all Pantone colours. HLS has proved to be a suitable colour system, because its parameters describe the colours in the similar way, to the human colour perception. (Figure 2).

The 3 elements of the HLS model are the following:

HUE in degree from 0 to 359 , where 0 is pure red, LUMINOSITY in percent, where $0=$ black, $50=$ bright colour, $100=$ white, SATURATION in percent, where $0=$ grey, $100=$ brightest.

The HLS model can be converted to any other standard colour systems, for example to RGB, used in monitors, or to CYMK used in printing processes, and to the platform free L*a*b code used colour analysers (Uddin et al., 2001).

Originally the flowers were described with 6 colours, but 3 of them are sufficient to determine the discolouring, which are the followings:

1: the petal colour of the opening bud, when the colour of the petals can be seen;

2: the surface colour of the petal of the young, partly-open flower;

3: the surface colour of the aged petal, when the flower is the widest in diameter.

To describe the colour of the petal, there was no sense in splitting the petals into mono-colour segments, which is essential in variety recognition (Zhenjiang et al., 2005). In each flower the typical colour was identified by determining the overall colour of the flower. The exact location of the determinant colour depends on the flower type: in the single form it was in the centre of the petal, but in the full or double flower the determining colour was found at the edge of the petals. The other parts of the petals are invisible.

To specify the degree of colour change, in the course of flower is ageing, two sets of values were calculated.

1. Change of colour, from the opening bud to the matured flower, thorough young flower stage. Colour shift was calculated according to the following method: Change of hue $\Delta \mathrm{H}_{1}=\left|\mathrm{H}_{1}-\mathrm{H}_{2}\right|+\left|\mathrm{H}_{2}-\mathrm{H}_{3}\right|$, change of luminosity $\Delta \mathrm{L}_{7}=\left|\mathrm{L}_{1}-\mathrm{L}_{2}\right|$ $+\left|\mathrm{L}_{2}-\mathrm{L}_{3}\right|$, change of saturation $\Delta \mathrm{S}_{1}=\left|\mathrm{S}_{1}-\mathrm{S}_{2}\right|+\left|\mathrm{S}_{2}-\mathrm{S}_{3}\right|$, where $1=$ bud stage, ${ }_{2}=$ young and ${ }_{3}=$ matured flower stage. Since the variances of the three parameters are different and not to be directly compared - for example the highest possible change is 100 at luminosity and at saturation, but 180 at hue 
- the final results are expressed in the percent of the mean value of $\Delta \mathrm{H}_{1}, \Delta \mathrm{L}_{1}$ and $\Delta \mathrm{S}_{1}$.

The following example describes the application of the method: The petal colour in the opening bud is dark middle red (hue $=1^{\circ}$ ), the young flower is fiery red $\left(h=7^{\circ}\right)$ and the aged flower is a little more purple $\left(\mathrm{h}=353^{\circ}\right.$ or $\left.-7^{\circ}\right)$. The hue change $(\ddot{\mathrm{A}} \mathrm{H} 1)$ of that flower is $|1-7|+|7-7|=6+14=20\left(^{\circ}\right)$. If the average of the change is $25^{\circ}$, it means, that the change of the hue from the bud, to the aged flower is $80 \%$ of the average colour hue shift.

2. Change of colour from the young flower to the mature flower stage. The method of calculating the colour shift is the following: Change of hue $\Delta \mathrm{H}_{2}=\mathrm{IH}_{2}-\mathrm{H}_{3} \mathrm{l}$, change of luminosity $\Delta \mathrm{L}_{2}=\left|\mathrm{L}_{2}-\mathrm{L}_{3}\right|$, change of saturation $\Delta \mathrm{S}_{2}=\left|\mathrm{S}_{2}-\mathrm{S} 3\right|$, where $2=$ young and $3=$ matured flower stage. The results are expressed in the percentage of the mean of $\Delta \mathrm{H}_{2}, \Delta \mathrm{L}_{2}$ and $\Delta \mathrm{S}_{2}$.

It is to be noted that the bud colour corresponds to the back of the petals, because when the bud is opening, only the back of the petal can be seen through the sepals. In the case of certain rose varieties the colour of the petal surface does not express the general colour of the flower, for example when the flower is full or rosette shaped. Here, the back of the curved petals may cover their upper side and the two colours blend into a colour that looks like the colour of the flower. In this case the general colour of the flower was measured. White roses, such as 'Szent Margit emléke' or 'Iceberg' were not studied.

\section{Results and Discussion}

In the present study well visible differences in the colour stability were studied in rose varieties.

As a first well definable, trait the colour stability of flowers was estimated. Table $I$ summarizes the results of observations on the colour change, (from the bud stage of the flower), whereas Table 2 shows data on the colour change from the partly-open flower stage. Only the most remarkable varieties are shown, the most colourfast roses and the varieties, with the strongest colour change.

According to Table 1 , only one non-fading variety was found, where the colour of the bud, i.e. young and aged petals are the same. This was the cultivar "Reményik Sándor emléke", a Hungarian floribunda cultivar. The discolouring of the variety 'Pest' was also very slight, its saturation and lightness shown only a little change. Remarkably, the way of change (lightening or darkening) cannot be specified because during the opening process the colour can first become darker, then later on lighter or in the case of the yellow colour, more or less yellow, initially, and more or less purple afterwards. While discolouring of 'Dick Koster Fulgens' was a result of the colour hue shifting, the flower of 'Border King' became duller. The petals of 'Régen' changed their lightness, although their colour hue and saturation remained more or less constant. The cultivars 'Minuette', 'Liu', 'Dsida Jenó emléke' and 'Colissée' are colourful roses, where the strong colour shift is the source of their attractiveness. For example
Table 1 Discolouring of flowers (from bud to matured flower): The ten varieties, which have the weakest, and the strongest colour change. The data are in percent of the average change.

\begin{tabular}{|c|c|c|c|c|c|}
\hline Variety & Class & $\begin{array}{l}\text { Hue } \\
\Delta H_{1}\end{array}$ & $\begin{array}{c}\text { Light- } \\
\text { ness } \\
\Delta \mathrm{L}_{1}\end{array}$ & $\begin{array}{c}\text { Satu- } \\
\text { ration } \\
\Delta S_{1}\end{array}$ & $\begin{array}{c}\text { Ave- } \\
\text { rage } \\
\text { of } \\
\Delta \mathrm{H}_{1} \text {, } \\
\Delta \mathrm{L}_{1} \text {, } \\
\Delta \mathrm{S}_{1}\end{array}$ \\
\hline Reményik Sándor emléke & $\mathrm{fl}$ & $0 \%$ & $0 \%$ & $0 \%$ & $0 \%$ \\
\hline Pest & $\mathrm{fl}$ & $6 \%$ & $21 \%$ & $28 \%$ & $18 \%$ \\
\hline Csl Cerveny Kriz & po & $48 \%$ & $25 \%$ & $11 \%$ & $28 \%$ \\
\hline Régen & fl & $6 \%$ & $87 \%$ & $13 \%$ & $35 \%$ \\
\hline Pernille Poulsen & $\mathrm{fl}$ & $29 \%$ & $46 \%$ & $39 \%$ & $38 \%$ \\
\hline Dick Koster Fulgens & po & $92 \%$ & $21 \%$ & $15 \%$ & $43 \%$ \\
\hline Kund Abigél & $\mathrm{fl}$ & $70 \%$ & $53 \%$ & $11 \%$ & $44 \%$ \\
\hline Fairy Damsel & po & $76 \%$ & $37 \%$ & $22 \%$ & $45 \%$ \\
\hline Border King & po & $41 \%$ & $21 \%$ & $76 \%$ & $46 \%$ \\
\hline Csinszka & po & $25 \%$ & $247 \%$ & $169 \%$ & $146 \%$ \\
\hline Borsod & po & $76 \%$ & $133 \%$ & $243 \%$ & $149 \%$ \\
\hline Vörössipkások emléke & $\mathrm{fl}$ & $115 \%$ & $179 \%$ & $195 \%$ & $161 \%$ \\
\hline Mrs.Joseph Hiess & $\mathrm{fl}$ & $356 \%$ & $37 \%$ & $104 \%$ & $165 \%$ \\
\hline Ady Endre emléke & $\mathrm{fl}$ & $229 \%$ & $114 \%$ & $160 \%$ & $167 \%$ \\
\hline Leila & $\mathrm{fl}$ & $325 \%$ & $78 \%$ & $295 \%$ & $231 \%$ \\
\hline Colisée & $\mathrm{fl}$ & $38 \%$ & $758 \%$ & $98 \%$ & $295 \%$ \\
\hline Dsida Jenö emléke & po & $678 \%$ & $247 \%$ & $48 \%$ & $323 \%$ \\
\hline Liu & $\mathrm{fl}$ & $509 \%$ & $256 \%$ & $241 \%$ & $334 \%$ \\
\hline Minuette & $\mathrm{fl}$ & $617 \%$ & $252 \%$ & $160 \%$ & $342 \%$ \\
\hline
\end{tabular}

Table 2 Discolouring of flowers (from young to matured flower):

The ten varieties, which have the weakest, and the strongest colour change. The data are in percent of the average change.

\begin{tabular}{|c|c|c|c|c|c|}
\hline Variety & Class & $\begin{array}{l}\text { Hue } \\
\Delta \mathrm{H}_{2}\end{array}$ & $\begin{array}{c}\text { Light- } \\
\text { ness } \\
\Delta \mathrm{L}_{2}\end{array}$ & $\begin{array}{c}\text { Satu- } \\
\text { ration } \\
\Delta S_{2}\end{array}$ & $\begin{array}{c}\text { Ave- } \\
\text { rage } \\
\text { of } \\
\Delta \mathrm{H}_{2} \text {, } \\
\Delta \mathrm{L}_{2} \text {, } \\
\Delta \mathrm{S}_{2}\end{array}$ \\
\hline Fairy Damsel & po & $0 \%$ & $0 \%$ & $0 \%$ & $0 \%$ \\
\hline Pest & $\mathrm{fl}$ & $0 \%$ & $0 \%$ & $0 \%$ & $0 \%$ \\
\hline Reményik Sándor emléke & $\mathrm{fl}$ & $0 \%$ & $0 \%$ & $0 \%$ & $0 \%$ \\
\hline Savaria & po & $0 \%$ & $0 \%$ & $0 \%$ & $0 \%$ \\
\hline Szent László emléke & $\mathrm{fl}$ & $0 \%$ & $0 \%$ & $0 \%$ & $0 \%$ \\
\hline Csl Cerveny Kriz & po & $22 \%$ & $14 \%$ & $0 \%$ & $12 \%$ \\
\hline Régen & $\mathrm{fl}$ & $0 \%$ & $47 \%$ & $0 \%$ & $16 \%$ \\
\hline Domokos Pál Péter emléke & $\mathrm{fl}$ & $29 \%$ & $5 \%$ & $17 \%$ & $17 \%$ \\
\hline Tornado & $\mathrm{fl}$ & $7 \%$ & $43 \%$ & $39 \%$ & $28 \%$ \\
\hline Lágymányos & $\mathrm{fl}$ & $253 \%$ & $85 \%$ & $11 \%$ & $120 \%$ \\
\hline Ady Endre emléke & $\mathrm{fl}$ & $260 \%$ & $47 \%$ & $122 \%$ & $143 \%$ \\
\hline Mrs. Joseph Hies & $\mathrm{fl}$ & $245 \%$ & $0 \%$ & $188 \%$ & $145 \%$ \\
\hline Munkács & $\mathrm{fl}$ & $375 \%$ & $76 \%$ & $105 \%$ & $147 \%$ \\
\hline Happy Event & $\mathrm{fl}$ & $188 \%$ & $142 \%$ & $299 \%$ & $210 \%$ \\
\hline Leila & $\mathrm{fl}$ & $36 \%$ & $152 \%$ & $687 \%$ & $292 \%$ \\
\hline Dsida Jenő emléke & po & $679 \%$ & $228 \%$ & $111 \%$ & $339 \%$ \\
\hline Minuette & $\mathrm{fl}$ & $765 \%$ & $398 \%$ & $200 \%$ & $454 \%$ \\
\hline Colisée & $\mathrm{fl}$ & $14 \%$ & $1418 \%$ & $72 \%$ & $501 \%$ \\
\hline Liu & $\mathrm{fl}$ & $1090 \%$ & $417 \%$ & $200 \%$ & $569 \%$ \\
\hline
\end{tabular}


Table 3 Discolouring of flowers (from bud to matured flower. average of the hue and the luminosity): The varieties, which have the weakest, and the strongest colour shift (lower than $50 \%$ or higher than $150 \%$ of the average change).

\begin{tabular}{|l|r|l|c|}
\hline Floribunda: & $\begin{array}{r}\text { Average } \\
\text { of } \\
\Delta \mathrm{H}_{1} \\
\text { and } \\
\Delta \mathrm{L}_{1}\end{array}$ & Polyantha: & $\begin{array}{c}\text { Average } \\
\text { of } \\
\Delta \mathrm{H}_{1} \\
\text { and } \\
\Delta \mathrm{L}_{1}\end{array}$ \\
\hline Reményik Sándor emléke & $0 \%$ & Beauty of New South Wells & $22 \%$ \\
\hline Pest & $13 \%$ & Border King & $31 \%$ \\
\hline Pernille Poulsen & $37 \%$ & Csl Cerveny Kriz & $36 \%$ \\
\hline Szabó Dezsö emléke & $40 \%$ & Szendrey Júlia emléke & $45 \%$ \\
\hline Barbecue & $42 \%$ & Savaria & $46 \%$ \\
\hline Poppy Flash & $47 \%$ & Domokos Pál Péter emléke & $48 \%$ \\
\hline Régen & $47 \%$ & & \\
\hline Nagyvárad & $48 \%$ & & \\
\hline Lilli Marleen & $50 \%$ & & \\
\hline & & & $171 \%$ \\
\hline Ady Endre emléke & $172 \%$ & Tihany & \\
\hline Leila & $201 \%$ & Mrs.Joseph Hiess & $197 \%$ \\
\hline Liu & $383 \%$ & Dsida Jenö emléke & $463 \%$ \\
\hline Colisée & $398 \%$ & & \\
\hline Minuette & $435 \%$ & & \\
\hline
\end{tabular}

Table 4 Discolouring of flowers (from young to matured flower, average of the hue and the luminosity): The varieties, which have the weakest, and the strongest colour shift (lower than $35 \%$ and higher than $150 \%$ of the average change).

\begin{tabular}{|l|c|l|c|}
\hline & $\begin{array}{c}\text { Average } \\
\text { of } \\
\Delta \mathrm{H}_{2} \\
\text { Fond } \\
\Delta \mathrm{L}_{2}\end{array}$ & Polyantha: & $\begin{array}{c}\text { Average } \\
\text { of } \\
\Delta \mathrm{H}_{2} \\
\text { and } \\
\Delta \mathrm{L}_{2}\end{array}$ \\
\hline Reményik Sándor emléke & $0 \%$ & Savaria & $0 \%$ \\
\hline Pest & $0 \%$ & Fairy Damsel & $0 \%$ \\
\hline Szent László & $0 \%$ & Domokos Pál Péter emléke & $17 \%$ \\
\hline Báthory István emléke & $13 \%$ & Csı Cerveny Kriz & $18 \%$ \\
\hline Régen & $24 \%$ & Border King & $34 \%$ \\
\hline Insel Mainau & $24 \%$ & & \\
\hline Nagyvárad & $25 \%$ & & \\
\hline Borsod & $26 \%$ & & \\
\hline Szabó Dezsö emléke & $35 \%$ & & \\
\hline & & & $226 \%$ \\
\hline Ady Endre emléke & $154 \%$ & Tihany & \\
\hline Happy Event & $165 \%$ & Dsida Jenö emléke & $453 \%$ \\
\hline Garden Princess & $169 \%$ & & \\
\hline Minuette & $582 \%$ & & \\
\hline Colisée & $716 \%$ & & \\
\hline Liu & $754 \%$ & & \\
\hline
\end{tabular}

'Dsida Jenö emléke', a Hungarian polyantha is butter-yellow at first, then it becomes soft-pink after opening, and then the petals gradually become dark salmon-red with white edge, and eventually almost white.

If the bud stage is omitted (Table 2), a lot of varieties can be distinguished with good non-fading flowers. 'Fairy
Damsel', 'Savaria', 'Szent László emléke' and 'Pest' proved to be practically non-fading, in addition to 'Reményik Sándor emléke'.

The three elements (hue, luminosity, saturation) cannot be measured with equal accuracy. It is hard to specify, if a very dark, or very light flower becomes duller or not. To avoid this type of error in Table 3 and Table 4) only the average of $\mathrm{H}$ and $\mathrm{L}$ components of the colour shift are shown, where the saturation is omitted.

According to Tables 3 and 4 , if only hue and saturation are taken into consideration, the cvs. 'Reményik Sándor emléke' and Pest' were the best non-fading floribundas. Both of them are Hungarian bred varieties. With regards to the colour of the bud, 'Perneille Poulsen was the least discolouring non Hungarian variety. If the bud stage is omitted, a lot of additional floribundas can be found with little colour fading, e.g.: the Hungarian varieties 'Szent László', 'Báthory István emléke', 'Régen', and the best foreign rose 'Insel Mainau'. In the polyantha class fewer varieties were non-fading or colourful. According to Table 3, Hungarian polyanthas have weaker colour stability than cvs. 'Beauty of New South Wells', 'Border King' and 'Csl Cerveny Kriz'. All polyantha varieties have a colour shifts to some degree. According to Table 4, the best Hungarian polyanthas were 'Savaria' and 'Domokos Pál Péter emléke', while 'Fairy Damsel' and 'Csl Cerveny Kriz' were the least colour-fading roses from Western Europe. 'Dsida Jenö emléke', 'Colisée' and 'Minuette' were the most colourful varieties.

Based on our observations it could be established that only a few varieties show strong colour stability throughout the whole life of their flowers. Most roses have constant colours only in the phenophase when their flowers are partly open and open. On the other hand some varieties have such a wide colour change, which is considered attractive and colourful. The HLS model of the colour space has revealed, that not only the light (or luminosity) of the flower can shift but also the hue is changeable in most of the cases. The three "dimensions" of the colour are independent, and they can shift also independently.

\section{Conclusion}

The rose varieties have been evaluated according to four characteristics: colour stability from the bud stage and from partly opened flower stage, with and without the saturation unit of the HLS colour model. Only those varieties were declared to be excellent in the colour stability of the flowers that showed good results in more than one evaluation. By summarizing our observations in a list of all varieties the best rose varieties could be selected (Table 5). "X" means that the variety was one of the best four in each observation. Because by the practice the most colour-stable roses are most desirable, colourful varieties with a strong and characteristic colour change have been omitted from the list of the best roses.

The list shows that valuable Hungarian varieties can be found in both studied classes, but more Hungarian bred 
Table 5 The roses with the highest colour stability of their flowers in our variety trial in 20003 at Budatétény. Meanings of the header are below the table.

\begin{tabular}{|l|l|l|l|l|}
\hline variety name, breeder, year & I & 2 & 3 & 4 \\
\hline floribundas & & & & \\
\hline Bäthory István emléke (Márk, -) & & & & $\mathrm{x}$ \\
\hline Pest (Márk, 1993) & $\mathrm{x}$ & $\mathrm{x}$ & $\mathrm{x}$ & $\mathrm{x}$ \\
\hline Perneille Poulsen (Poulsen, 1965) & $\mathrm{x}$ & & $\mathrm{x}$ & \\
\hline Régen (MÁrk, 2000) & $\mathrm{x}$ & $\mathrm{x}$ & & \\
\hline Reményik Sándor emléke (Márk, -) & $\mathrm{x}$ & $\mathrm{x}$ & $\mathrm{x}$ & $\mathrm{x}$ \\
\hline Szent László emléke (Márk, 2002) & & $\mathrm{x}$ & & $\mathrm{x}$ \\
\hline Szabó Dezsö emléke (Márk, 19989) & & & $\mathrm{x}$ & $\mathrm{x}$ \\
\hline polyanthas & & & & \\
\hline Beauty of New south Wells (Knight, 1931) & & & $\mathrm{x}$ & \\
\hline Border King (deRuiter, 1952) & $\mathrm{x}$ & & $\mathrm{x}$ & \\
\hline Csl Cerveny Kriz (Böhm, 1937) & $\mathrm{x}$ & $\mathrm{x}$ & $\mathrm{x}$ & $\mathrm{x}$ \\
\hline Domokos Pál Péter emléke (Márk, 1998) & & $\mathrm{x}$ & & $\mathrm{x}$ \\
\hline Dick Koster Fulgens (Koster, 1940) & $\mathrm{x}$ & & & \\
\hline Fairy Damsel (Harkness, 1982) & $\mathrm{x}$ & $\mathrm{x}$ & & $\mathrm{x}$ \\
\hline Szendrey Júlia emléke (Márk, -) & & & $\mathrm{x}$ & \\
\hline Savaria (Márk, -) & & $\mathrm{x}$ & & $\mathrm{x}$ \\
\hline
\end{tabular}

Meaning of the header of Table 5:

Best non-fading varieties (bud to matured flower), according to Table 2 (4 varieties)

2 - Best non-fading varieties (young to matured flower), according to Table 3 (4 varieties)

3 - Best non-fading varieties; hue, luminosity only (bud to matured flower). according to Table 4 (4 varieties)

4 - Best non-fading varieties; hue, luminosity only (young to matured flower), according to Table 5 (4 varieties)

floribundas had a better colour stability than the polyanthas. The best Hungarian floribundas were 'Pest' and 'Reményik Sándor emléke', although 'Régen', 'Szent László emléke' and 'Szabó Dezsö emléke' were quite good. The best WesternEuropean floribunda rose was 'Perneille Poulsen'. Their colour stability was reliable in different situations. Changing of the colour of the two best varieties was almost unperceivable from the bud to the young petals and from the young to the aged petals. 6 out of the 7 good varieties were bred in Hungary that means the floribunda roses - especially red varieties - have a better colour stability than many well known Western European roses. In the polyantha class there was only one perfect variety: the Czech 'Csl Cerveny Kriz'. The 'Fairy Damsel' was excellent in 3 evaluations out of 4 . The best Hungarian polyanthas were 'Domokos Pál Péter emléke' and 'Savaria'. In general, polyanthas have weaker colour stability, because the hardiness and compactness of that class is more important, than the flower quality. It is true even the Hungarian polyanthas, although 'Domokos Pál Péter emléke' has really very good stability. According to the evaluations, among the Hungarian roses 'Reményik Sandor emléke' has the strongest colour stability, this variety candidate is bred by Gergely Márk.

\section{References}

Cairns, T., Young, M., Adams, J. \& Edberg B. eds (2000), Modern Roses XI. The World Encyclopaedia of Roses, Shrevport, USA, American Rose Society.

H. Voss, D. (1992) Relating Colorimeter Measurment of Plant Color to the Royal Horticultural Society Colour Chart, HortScience $27(12): 1256-1260$.

Márk, G. (2004) Magyar rózsák könyve, Budapest, Hungary, Mezögazda Kiadó 2004.

Pécsi, M. ed. (1989) National Atlas of Hungary, Budapest, Hungary., Mezögazda Kiadó.

Rátkai, J. ed (2001), National List of Varieties, Budapest, Hungary. National Institute For Agricultural Quality Control.

Palai, S., Mishra, M., Bhuyan, S. \& Mishra H., (2003), Genetic variability in hybrid tea roses, Journal of Ornamental Horticulture -New-Series, 6: (1): 29-33.

Royal Horticultural Society (1986), Royal Horticultural Society colour chart. Royal Hort. Soc., London and Flower Council of Holland, Leiden.

Uddin, A.F.M.J., Hashimoto, F, Kaketani, M., Shimizu, K. \& Sakata, Y. (2001), Analysis of light and sucrose potencies on petal coloration and pigmentation of Lisianthus cultivars (in vitro), Scienta Horticulturae 89: 73-82.

Zhenjiang, M., Gandelin M.H. \& Baozong, Y. (2005), An OOPRbased rose variety recognition system, Engineering Applications of Artifical Intelligence 19: 79-101. 